UTILITY: Jurnal IImiah Pendidikan dan Ekonomi

Volume 5, No. 2, Agustus 2021: Page 1-10

ISSN 2549-1377 (Print) || ISSN 2549-1385 (Online)

Available online at http://journal.stkipnurulhuda.ac.id/index.php/utility

\title{
FAKTOR-FAKTOR YANG MEMPENGARUHI STRUKTUR MODAL DAN PENGARUHNYA TERHADAP RETURN ON EQUITY PERUSAHAAN MANUFAKTUR DI BURSA EFEK INDONESIA
}

\author{
Hatidah $^{1}$ \\ ${ }^{1}$ Politeknik Darussalam \\ *E-mail: Hatidah14@gmail.com
}

\begin{abstract}
Abstrak: Penelitian ini bertujuan untuk menganalisis pengaruh arus kas bebas, struktur aktiva dan pertumbuhan penjualan terhadap struktur modal; menganalisis pengaruh arus kas bebas, struktur aktiva, pertumbuhan penjualan dan struktur modal secara langsung terhadap ROE; dan menganalisis pengaruh arus kas bebas, struktur aktiva, dan pertumbuhan penjualan secara tidak langsung terhadap ROE melalui struktur modal pada perusahaan manufaktur yang tercatat di Bursa Efek Indonesia. Penelitian ini menggunakan regresi linear berganda. Hasil penelitian menunjukkan bahwa struktur aktiva berpengaruh positif dan signifikan terhadap struktur modal; pertumbuhan penjualan berpengaruh positif dan signifikan, terhadap ROE serta struktur modal berpengaruh negatif dan signifikan terhadap ROE; arus kas bebas, struktur aktiva dan pertumbuhan penjualan memiliki pengaruh secara tidak langsung terhadap ROE melalui struktur modal.
\end{abstract}

Kata Kunci: : struktur modal, ROE, arus kas bebas, struktur aktiva, pertumbuhan penjualan, regresi linear berganda, analisis jalur.

\section{PENDAHULUAN}

Tujuan perusahaan dalam jangka panjang adalah mengoptimalkan nilai perusahaan dengan meminimumkan biaya modal perusahaan. Semakin tinggi nilai perusahaan, menggambarkan kinerja perusahaan yang baik. Kinerja perusahaan dapat dilihat dari kemampuan perusahaan dalam memberikan keuntungan dari aset, ekuitas dan hutang. Salah satu ukuran kinerja perusahaan adalah Return on Equity (ROE) yang digunakan untuk mengukur efektivitas perusahaan dalam menghasilkan keuntungan dengan memanfaatkan total ekuitas yang dimilikinya. Semakin besar ROE menunjukkan kinerja perusahaan semakin baik dengan tingkat pengembalian yang diharapkansemakin besar.

Menurut Brigham dan Houston (2018), perusahaan dengan rasio hutang relatif tinggi, memiliki ekspektasi pengembalian yang juga lebih tinggi ketika kondisi perekonomian stabil, namun memiliki risiko kerugian ketika ekonomi mengalami masa resesi. Oleh sebab itu, keputusan akan penggunaan hutang mengharuskan 
perusahaan menyeimbangkan tingkat ekspektasi pengembalian yang lebih tinggi dengan risiko yang meningkat.

Teori keagenan menurut Fahmi (2014) menyatakan bahwa manajemen atau agen harus bekerja dengan maksimal untuk memberikan kepuasan yang tinggi bagi pemilik perusahaan atau principal. Hal ini dapat berdampak terjadinya sikap oportunistik pada manajemen atau agen dengan melakukan tindakan-tindakan yang disengaja seperti melaporkan piutang tak tertagih lebih besar dari seharusnya, tidak melaporkan hasil penjualan sesuai dengan sebenarnya, melaporkan pendapatan yang tidak sesuai dengan sebenarnya, dan melaporkan pengeluaran yang tidak sesuai dengan kebutuhan yang sebenarnya.

Penelitian ini menggunakan variabel struktur modal dan ROE sebagai variabel dependen sedangkan variabel independen yang digunakan adalah arus kas bebas, struktur aktiva, pertumbuhan penjualan dan struktur modal. Penelitian ini untuk menguji pengaruh arus kas bebas, struktur aktiva dan pertumbuhan penjualan terhadap struktur modal; menguji pengaruh arus kas bebas, struktur aktiva, pertumbuhan penjualan, dan struktur modal terhadap ROE pada perusahaan manufaktur yang tercatat di Bursa Efek Indonesia.

Alasan dipilinnya ketiga rasio tersebut adalah : (1) Arus kas bebas yang tinggi mengindikasikan kinerja perusahaan yang baik. Kinerja dari perusahaan yang baik akan meningkatkan nilai pemegang saham yang diwujudkan dalam bentuk return yang tinggi melalui dividen, harga saham, atau laba ditahan untuk diinvestasikan di masa depan. Namun, untuk mengurangi konflik keagenan, perusahaan didorong untuk meningkatkankan jumlah hutang, sehingga manajer menjadi lebih disiplin dalam berinvestasi dan penggunaan aktiva menjadi lebih produktif. Adapun proporsi hutang disesuaikan dengan pertumbuhan penjualan. Karena pertumbuhan penjualan yang rendah akan berpengaruh pada rendahnya jumlah arus kas bebas. (2) Perusahaan dengan jumlah aktiva tetap yang besar lebih mudah mengakses dana eksternal dibandingkan dengan perusahaan kecil. Hal ini karena adanya jaminan hutang berupa aktiva tetap dalam jumlah besar. Dan adanya hutang diharapkan akan meningkatkan penjualan dalam menghasilkan laba. Namun, jumlah aktiva tetap lebih besar dibandingkan dengan aktiva lancar memberikan pengaruh terhadap kinerja peruahaan. Penggunaan hutang yang besar di satu sisi akan meningkatkan financial risk, sementara sisi yang lain adanya aktiva tetap dalam jumlah besar akan memperbesar bussiness risk (degree of operating leverage) dan pada akhirnya total risk meningkat (Sartono, 2016). (3)Semakin cepat pertumbuhan penjualan, kebutuhan akan modal semakin besar untuk pembiayaan ekspansi. Tingginya pertumbuhan penjualan akan memberikan kemudahan perusahaan dalam mengakses sumber dana eksternal. Dan perusahaan mempunyai kecenderungan untuk menahan laba karena tingginya kebutuhan akan dana di masa mendatang. Sehingga jumlah deviden yang akan dibagikan semakin kecil.

Selain berdampak langsung terhadap struktur modal dan ROE, ketiga variabel di atas dapat berpengaruh secara tidak langsung terhadap ROE melalui struktur modal. Karena hutang digunakan untuk mendanai aktiva yang diharapkan dapat meningkatkan penjualan dan berpengaruh pada kinerja perusahaan. 


\section{FAKTOR-FAKTOR YANG MEMPENGARUHI STRUKTUR MODALDAN PENGARUHNYA TERHADAP RETURN ON EQUITY PERUSAHAAN MANUFAKTUR DI BURSA EFEK INDONESIA}

\section{METODE}

Penelitian ini menggunakan regresi dengan analisis jalur. Tujuan regresi dengan analisis jalur ini adalah menguji pengaruh arus kas bebas, struktur aktiva, dan pertumbuhan penjualan terhadap struktur modal; menguji pengaruh secara langsung arus kas bebas, struktur aktiva, pertumbuhan penjualan, dan struktur modal terhadap ROE; serta menguji pengaruh tidak langsung arus kas bebas, struktur aktiva, dan pertumbuhan penjualan terhadap ROE melalui struktur modal.

Obyek penelitian ini adalah perusahaan dalam industri manufaktur yang terdaftar di Bursa Efek Indonesia periode 2005-2010. Jenis data yang digunakan adalah data sekunder yang dipublikasikan perusahaan melalui website Bursa Efek Indonesia.

Metode pengumpulan data dalam penelitian ini adalah menentukan data mana yang akan menjadi bagian yang akan diteliti (arus kas bebas, struktur aktiva, pertumbuhan penjualan, struktur modal, ROE) dan menunjukkan bagaimana sumber tersebut diperoleh. Data informasi diperoleh dari :

1. Situs resmi Bursa Efek Indonesia yang mempublikasikan laporan keuangan emiten dan jurnal yang terkait dengan penelitian.

2. Studi kepustakaan yang terkait dengan penelitian sebagai bahan referensi perbandingan teori, penerapannya dan kenyataan di lapangan.

Pokok permasalahan dalam penelitian ini dapat dijawab dengan alat analisis data berupa analisis jalur dengan analisis linear berganda. Analisis jalur digunakan karena terdapat kemungkinan hubungan antar variabel dalam model yang bersifat linear.

Langkah-langkah untuk menganalisis data sebagai berikut :

1. Menghitung variabel dependen dan independen untuk variabel penelitian dari tahun 2005-2010.

2. Menganalisis data yaitu menentukan rata-rata, maksimum, minimum, dan standar deviasi.

3. Membuat model yang akan digunakan dalam penelitian dan menentukan nilai yang sesuai untuk variabel dependen dan independen serta validasi model penelitian.

4. Menguji hipotesis yang diajukan dalam penelitian.

Pengujian hipotesis dilakukan dengan uji statistik regresi dan korelasi dengan analisis jalur. Analisis regresi bertujuan untuk mengujii pengaruh langsung nilai variabel independen terhadap nilai variabel dependen maupun pengaruh tidak langsung variabel independen terhadap nilai variabel dependen melalui variabel intervening. Sehingga dapat diukur kekuatan dan arah hubungan antara variabel dependen dan variabel independen (Ghozali, 2015) 


\section{HASIL DAN PEMBAHASAN}

\section{HASIL}

Penelitian ini menggunakan metode analisis regresi linear berganda. Persamaan model regresi akan menunjukkan hubungan yang signifikan dan representatif, apabila model tersebut memenuhi asumsi klasik. Dan uji asumsi klasik yang digunakan dalam penelitian ini adalah uji normalitas, multi kolinearitas, auto korelasi, dan heteros kedastisitas. Setelah model memenuhi asumsiklasik, lalu dilakukan goodness of fit model yang meliputi : koefisien determinasi (Adjusted $\mathrm{R}^{2}$ ), uji hipotesis melalui uji-t dan uji-F untuk menentukan ketepatan model.

Tabel 1 merupakan hasil uji normalitas untuk persamaan model pertama dimana variabel dependen adalah struktur modal dan variabel independen terdiri atas arus kas bebas, struktur aktiva, dan pertumbuhan penjualan.

Tabel 1. HasilUjiNormalitas (Persamaan Model Pertama) One-Sample Kolmogorov-Smirnov Test

\begin{tabular}{|c|c|c|}
\hline & & $\begin{array}{l}\text { Unstandard } \\
\text { ized Residual }\end{array}$ \\
\hline \multirow{6}{*}{$\begin{array}{c}\text { Most } \\
\text { Differences }\end{array}$} & & 144 \\
\hline & Mean & .0000000 \\
\hline & $\begin{array}{l}\text { Std. } \\
\text { riation }\end{array}$ & .95689639 \\
\hline & Absolute & .104 \\
\hline & Positive & .104 \\
\hline & Negative & -.061 \\
\hline Kolmogorov-Smirnov Z & & 1.243 \\
\hline Asymp. Sig. (2-tailed) & & .091 \\
\hline
\end{tabular}

a. Test distribution is Normal.

\section{Sumber : Output SPSS}

BerdasarkanTabel 1 diketahui bahwa nilai Kolmogorov-Smirnov sebesar 1,243 dengan probabilitas signifikansi 0,091 yang menunjukkan bahwa asumsi normalitas terpenuhi (sig. $>0,05$ pada $\alpha=0,05$ ).

Tabel 2 merupakan hasil uji normalitas untuk persamaan model kedua dimana variabel dependen adalah $R O E$ dengan variabel independen yang teridiri atas arus kas bebas, struktur aktiva, pertumbuhan penjualan, dan struktur modal. Dan berdasarkanTabel 5.5 diketahui bahwa nilai Kolmogorov-Smirnov 0,978 dengan probabilitas signifikansi 0,295 yang menunjukkan bahwa asumsi normalitas terpenuhi( sig. $>0,05$ pada $\alpha=0,05$ ).

Tabel 2. HasilUjiNormalitas (Persamaan Model Kedua)

One-Sample Kolmogorov-Smirnov Test 


\section{FAKTOR-FAKTOR YANG MEMPENGARUHI STRUKTUR MODALDAN PENGARUHNYA TERHADAP RETURN ON EQUITY PERUSAHAAN MANUFAKTUR DI BURSA EFEK INDONESIA}

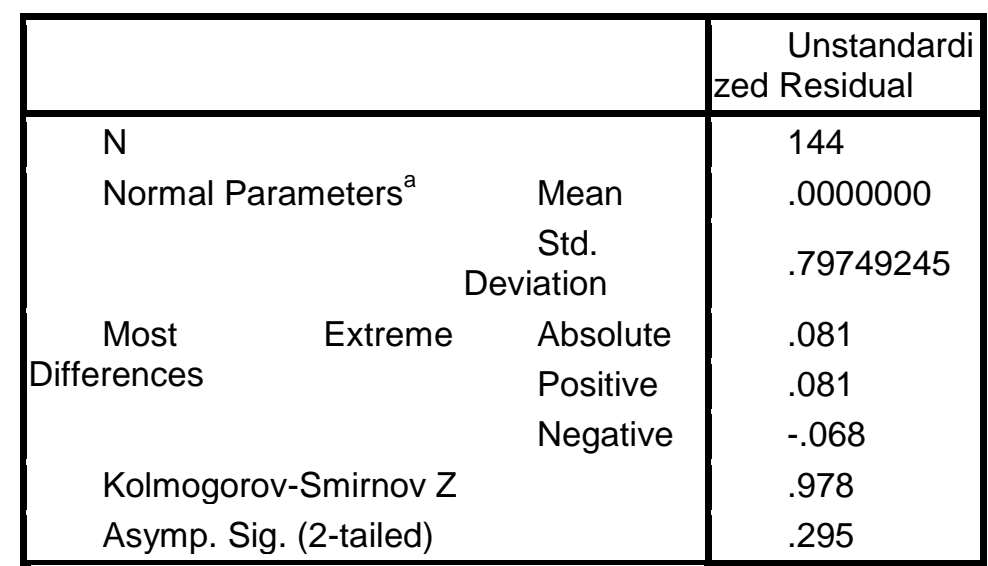

a. Test distribution is Normal.

Sumber : Output SPSS

\section{Uji Multikolinearitas}

Uji multikolinearitas bertujuan untuk menguji apakah model regresi ditemukan adanya korelasi antarvariabel independen. Untuk mendeteksi adatidaknya multikolinearitas antarvariabel independen digunakan nilai tolerance danvariance inflation factor (VIF). Nilai yang mengindikasikan adanya multi kolinearitas adalah apabila nilai tolerance $<0,10$ dan nilai $\mathrm{VIF}>10$.

Nilai tolerance dan VIF menunjukkan setiap variabel independen manakah yang dijelaskan oleh variabel independen lainnya. Atau dengan kata lain setiap variabel independen menjadi variabel dependen dan diregresi terhadap variabel independen lainnya.

Tabel 3merupakan hasil nilai tolerance dan VIF untuk persamaan model pertama dimana variabel dependen adalah struktur modal dan variabel independen adalah arus kas bebas, struktur aktiva dan pertumbuhan penjualan.

Tabel 3. HasilPerhitungan Tolerancedan VIF(Persamaan Model Pertama)

Coefficients $^{a}$

\begin{tabular}{|c|c|c|}
\hline \multirow[b]{2}{*}{ Model } & \multicolumn{2}{|c|}{ Collinearity Statistics } \\
\hline & ce Toleran & VIF \\
\hline (Constant) & & \\
\hline LnAKB & .784 & 1.276 \\
\hline SA & .789 & 1.267 \\
\hline PP & .982 & 1.019 \\
\hline
\end{tabular}

Dependent Variable: LnSM

Sumber : Output SPSS 
Berdasarkan Tabel 3 diketahui bahwa tidak ada nilaitolerance $<0,10$ dannilai VIF $>10$. Artinya tidak terdapat multikolinearitas data residual pada variabel arus kas bebas, struktur aktiva dan pertumbuhan penjualan .

Mendeteksi adanya multikolinearitas pada suatu model dapat juga dilihat dari korelasi antar variabel independen. Jika korelasi antarvariabel independen> 0,95 dapat diindikasikan adanya multikolinearitas.

Berdasarkan Tabel 4 diketahui bahwa tidak ada nilai korelasi yang lebih besar dari 0,95 . Korelasi yang cukup kuat terlihat antara struktur aktiva dan arus kas bebas sebesar 0,457. Namun nilai tersebut masih dibawah 0,95. Sehingga dapat dikatakan tidak ada korelasi antar variabel arus kas bebas, struktur aktiva dan pertumbuhan penjualan atau persamaan model pertama tidak ada multikolinearitas. Dan adanya korelasi yang tinggi antar variabel independen ini terjadikarena data time series bergerak naik dan turun secara bersamaan. Hasil perhitungan struktur aktiva dan arus kas bebas menunjukkan adanya nilai yang besar yang dapat berkorelasi antara keduanya.

\section{Tabel 4.Koefisien Korelasi antarVariabel Independe n(Persamaan Model} Pertama)

\begin{tabular}{|c|c|c|c|c|c|}
\hline \multicolumn{3}{|l|}{ Model } & PP & SA & B LnAK \\
\hline \multirow{3}{*}{$11 \mathrm{~s}$} & Correlation & PP & 1.000 & .098 & -.128 \\
\hline & & SA & .098 & 1.000 & -.457 \\
\hline & & $\operatorname{Ln} A$ & -.128 & -.457 & 1.000 \\
\hline \multirow{3}{*}{ es } & Covarianc & PP & .158 & .024 & -.003 \\
\hline & & SA & .024 & .362 & -.016 \\
\hline & & $\operatorname{Ln} A$ & -.003 & -.016 & .003 \\
\hline
\end{tabular}

a. Dependent Variable: LnSM

Sumber : Output SPSS

Tabel 5 merupakan hasil perhitungan tolerance dan VIF untuk persamaan model kedua dimana variabel dependen adalah ROE dan variabel independen adalah arus kas bebas, struktur aktiva, pertumbuhan penjualan, dan struktur modal.

\section{Tabel 5.}

\section{HasilPerhitungan Tolerance dan VIF(Persamaan Model Kedua) Coefficients $^{\mathbf{a}}$}


FAKTOR-FAKTOR YANG MEMPENGARUHI STRUKTUR MODALDAN PENGARUHNYA TERHADAP RETURN ON EQUITY PERUSAHAAN MANUFAKTUR DI BURSA EFEK INDONESIA

\begin{tabular}{|c|c|c|}
\hline \multirow[b]{2}{*}{ Model } & \multicolumn{2}{|c|}{$\begin{array}{l}\text { Collinearity } \\
\text { Statistics }\end{array}$} \\
\hline & ce ${ }^{\text {Toleran }}$ & VIF \\
\hline nt) ${ }^{\text {(Consta }}$ & & \\
\hline LnAKB & .782 & 1.278 \\
\hline LnSM & .792 & 1.263 \\
\hline SA & .666 & 1.500 \\
\hline PP & .974 & 1.027 \\
\hline
\end{tabular}

a. Dependent Variable: LnROE

\section{Sumber : Output SPSS}

Berdasarkan Tabel 5 diketahui bahwa tidak ada nilai tolerance $<0.10$ atau pun nilai VIF $>10$. Artinya tidak terjadi multi kolinearitas dalam data residual variabel arus kas bebas, struktur aktiva, pertumbuhan penjualan dan struktur .

Tabel 6 adalah hasil koefisien korelasi antar variabel arus kas bebas, strutur aktiva, pertumbuhan penjualan dan struktur modal yang menunjukkan tidak ada nilai yang melebihi 0,95 . Nilai koefisien yang cukup tinggi antara struktur aktiva dan arus kas bebas sebesar 0,402 dan struktur aktiva dan struktur modal sebesar 0,394. Namun nilai koefisien tersebut masih dibawah 0,95 . Sehingga dapat dikatakan bahwa tidak terjadi multikolinieritas antar arus kas bebas, struktur aktiva, pertumbuhan penjualan dan arus kas bebas.

Tabel 6. KoefisienKorelasiantarVariabellndependen(Persamaan Model

\section{Kedua)}

\section{Coefficient Correlations ${ }^{a}$}

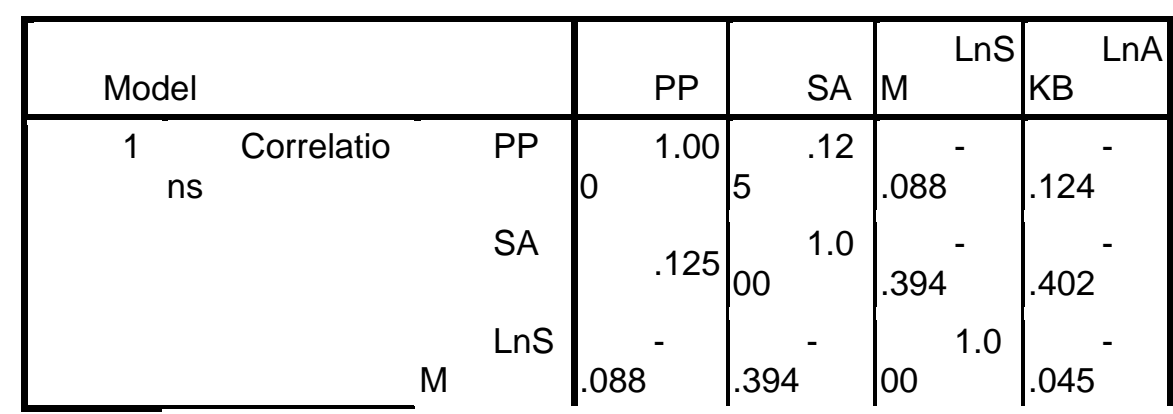




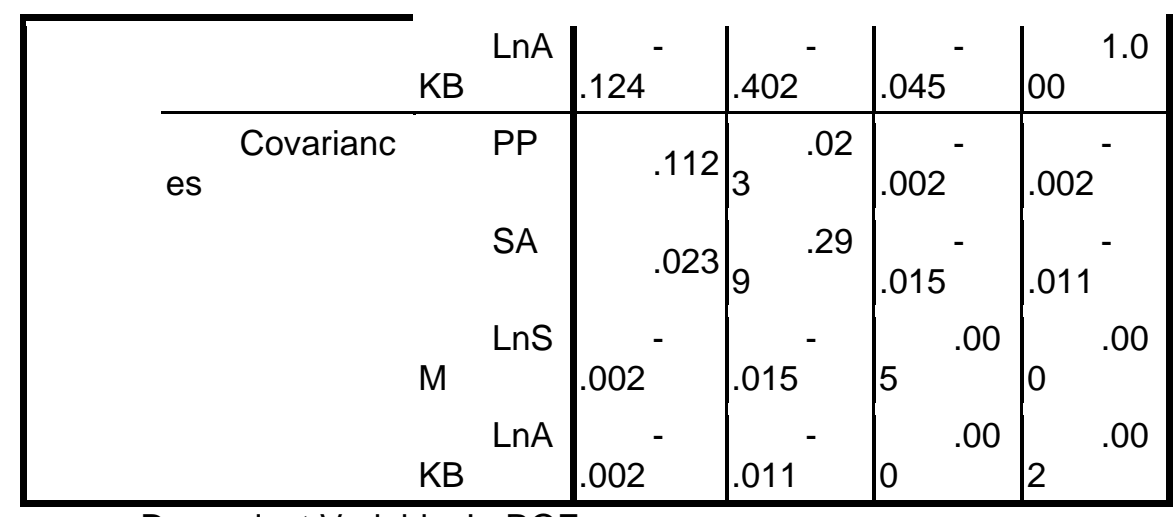

a. Dependent Variable: LnROE

Sumber : Output SPSS

\section{Pembahasan}

Hasil regresi menunjukkan bahwa struktur modal berpengaruh signifikan negatif terhadap ROE.Sehingga hipotesis yang diajukan bahwa arus kas bebas, struktur aktiva dan pertumbuhan penjualan berpengaruh terhadap ROE melalui struktur modal $\left(\mathrm{H}_{10}\right)$ dapat diterima. Nilai negatif struktur modal menunjukkan semakin baik kinerja keuangan dalam memanfaatkan ekuitasnya, sehingga penggunaan hutang jangka panjang dalam aktivitas perusahaan akan turun. Hal ini dipengaruhi oleh semakin baiknya pertumbuhan penjualan yang memberikan pengaruhpositifpadalabaperusahaan.

Hasil menunjukkan bahwa nilai pengaruh tidak langsung arus kas bebas, struktur aktiva dan pertumbuhan penjualan terhadap ROE melalui struktur modal lebih besar(-0,115) dibandingkan dengan pengaruh langsung struktur modal terhadap ROE $(-0,208)$. Hal ini menujukkan bahwa saat posisi ROE tinggi, maka hutang jangka panjang akan turun bila pertumbuhan penjualan, arus kas bebas dan struktur aktiva cukup stabil yang berpengaruh pada kinerja perusahaan.

Secara parsial, struktur aktiva dan arus kas bebas tidak signifikan berpengaruh langsung terhadap ROE. Sedangkan secara tidak langsung, struktur aktiva dan arus kas bebas signifikan dan berpengaruh terhadap ROE melalui struktur modal. Hal ini terkait dengan biaya modal yang bertindak sebagai penghubung antara keputusan pembiayaan dan investasinya. Biaya modal menjadi batasan yang harus dicapai oleh sebuah investasi sebelum meningkatkan kekayaan pemiliknya. Perubahan struktur modal akan mempengaruhi biaya modal. Biaya modal akan semakin menurun dengan makin besarnya komposisi hutang yang digunakan dan meningkatkan nilai perusahaan. Tetapi, semakin tinggi tingkat hutang akan meningkatkan risiko yang harus ditanggung perusahaan. Dengan proporsi hutang yang semakin besar, berpengaruh pula pada perolehan rating perusahaan.

Penambahan modal asing berupa hutang jangka panjang hanya dapat dibenarkan jika penambahan tersebut mempunyai pengaruh yang menguntungkan terhadap ekuitas. Penambahan hutang jangka panjang hanya akan memberi efek 


\section{FAKTOR-FAKTOR YANG MEMPENGARUHI STRUKTUR MODALDAN PENGARUHNYA TERHADAP RETURN ON EQUITY PERUSAHAAN MANUFAKTUR DI BURSA EFEK INDONESIA}

menguntungkan terhadap ekuitas apabila rate of return (ROR) dari tambahan hutang jangka panjang tersebut lebih besar daripada biaya modalnya. Sebaliknya penambahan hutang jangka panjang akan memberikan efek merugikan terhadap ekuitas apabila ROR dari tambahan hutang jangka panjang tersebut lebih kecil daripada biaya modal atau bunganya.

\section{SIMPULAN}

Berdasarkan hasil analisis dan pembahasan dapat disimpulkan bahwa :

1. Struktur aktiva berpengaruh positif dan signifikan terhadap struktur modal. Sedangkan arus kas bebas, dan pertumbuhan penjualan tidak berpengaruh terhadap struktur modal.

2. Pertumbuhan penjualan berpengaruh positif dan signifikan terhadap ROE; struktur modal berpengaruh negatif dan signifikan terhadap ROE. Sedangkan struktur aktiva dan arus kas bebas tidak berpengaruh secara langsung terhadap ROE.

3. Secara tidak langsung arus kas bebas, struktur aktiva, dan pertumbuhan penjualan berpengaruh terhadap ROE melalui struktur modal.

\section{UCAPAN TERIMAKASIH}

Ucapan terima kasih saya persembahkan Prof. Dr. Hj. Sulastri, M.E., M.Kom.dan Drs. A. Gani Harun, S.U.sebagai pembimbing Tesisini yang telah memberikan bimbingan dan arahan dalam penyusunan ini. Kedua orang tua dan keluarga serta teman-teman Magister Manajemen yang selalu memberikan dukungan. Kemudian, khsususnya bagi pengelola jurnal UTILITY yang telah bersedia menerbitkan tulisan ini. Terimakasih.

\section{REFERENSI}

Brigham, E.F.,J.F. Houston. 2018. Dasar-dasarManajemenKeuangan, Edisi 14. Jakarta: SalembaEmpat.

Fahmi, Irham. 2014. PengantarManajemenKeuangan. Bandung : Alfabeta.

Ghozali, Imam. 2015. AplikasiAnalisisMultivariatdengan Program IBM SPSS 19, Edisikelima.Semarang : BP UniversitasDiponegoro.

PancawatiHardiningsih, RachmawatiMeitaOktaviani. 2012. DeterminanKebijakanHutang (Dalam Agency Theory dan Pecking Order Theory).DinamikaAkuntansi, KeuangandanPerbankan. Volume 1(1) : 11-24.

Kasmir. 2012. AnalisisLaporankeuangan. Jakarta : Raja GrafindoPersada.

ZakaYahya Putra. 2017. PengaruhkasBebas, ProfitabilitasdanUkuran Perusahaan terhadapKebijakanUtang. JurnalllmudanRisetAkuntansi. Volume 6 (3). 
Rachmawardani, Yulinda. 2007. Analisis Pengaruh Aspek Likuiditas, Risiko Bisnis, Profitabilitas, dan Pertumbuhan Penjualan terhadap Struktur Modal Perusahaan (Studi empiris pada sektor keuangan dan perbankan di BEJ Tahun 2000-2005). Tesis. Semarang : PPS Universitas Diponegoro.

Riyanto, Bambang. 2013. Dasar-Dasar Pembelanjaan Perusahaant. Yogyakarta: BPFE.

Ross, R.W. Westerfield, J.F. Jordan, B.D. 2013. Fundamental ofCorporate Finance, $10^{\text {th }}$ Edition.New York: McGraw-Hill.

Sartono, Agus. 2016. Manajemen Keuangan Teori dan Aplikasi. Yogyakarta : BPFE Yogyakarta.

Jeni Susanti. 2014. Faktor-Faktor Berpengaruh Pada Capital Structure Pada Industri Mining di Bursa Efek Indonesia. Jurnal Valid, Volume 11(2) : 18-25.

Wicaksana, P.K.A. 2017. Good Corporate Governance Sebagai Pemoderasi Pengaruh Arus Kas Bebas pada Praktik Income Minimization. E-Jurnal Akuntansi Universitas Udayana. Volume 20(3) : 2016-2044 